УДК 94 (477.83)

DOI 10.24919/2519-058X.5.116988

Богдан ЯНИШИН, orcid.org/0000-0003-0386-2530 кандидат історичних наук, старший науковий співробітник відділу історї України XIXпочатку XX ст. Інституту історії України НАН Украӥни

(Київ, Україна), bogdanyanyshyn@gmail.com

\title{
СХІДНОГАЛИЦЬКЕ ШКІЛЬНИЦТВО АВТОНОМІЧНОЇ ДОБИ У ВИБРАНІЙ ПОЛЬСЬКІЙ ІСТОРІОГРАФІЇ
}

Стаття присвячена особливостям дослідження проблем освіти в Східній Галичині автономічної доби у вибраній сучасній польській історіографії. Розглянуто різнопланові праці, присвячені становленню і розвитку народного, середнього та вищзого шкільництва. Зроблено висновок про значну популярність иієї проблеми, з огляду на потужний модернізаційний вплив шкільництва на всі сфери суспільного життя.

Ключові слова: польська історіографія, освіта, шкільництво, елементарні иколи, гімназіі, університет, модернізація.

תim. 31.

Bohdan YANYSHYN,

Ph D (History), Senior Research Fellow of Department of History of Ukraine of the XIX-early XX cc., Institute of History of Ukraine of the NAS of Ukraine

(Kyiv, Ukraine), bogdanyanyshyn@gmail.com

\section{EASTERN GALICIAN SCHOOLING OF THE ERA OF AUTONOMY IN THE SELECTED POLISH HISTORIOGRAPHY}

The article is devoted to the peculiarities of the study of problems of the Eastern Galician schooling in the second half of the nineteenth and early twentieth centuries as represented in a selection of contemporary Polish historiography. It is emphasized that the period of Galicia's autonomy is traditional and one of the most popular periods in the works of Polish researchers of the past. At the same time, a special attention is paid to the educational processes, which, due to the self-governing status of the region, showed the greatest positive dynamics in comparison to other spheres of social life. It is the success of schooling at all levels that contributed to the consolidation of the national consciousness of the masses, successful overcoming of illiteracy, education of a number of intellectuals, who later formed an effective state apparatus in the early years of the restoration of independence.

Polish works devoted to the problems of formation and development of national, secondary and higher schooling have been analyzed. It has been found out that Polish researchers also pay much attention to women's schooling, adult education, and the financing of the educational sector. It is indicated that the pedagogical environment of autonomous Galicia is also in the focus of Polish researchers. In numerous works they noted the existence of stereotypes in the comprehension of Ukrainian schooling in the region, which had been inherited from the era of acute inter-ethnic confrontations.

The analysis made it possible to underline a considerable interest of Polish scientists in various problems and forms of the East-Galician school of the autonomous age. Researchers are unanimous in their conclusions on the exclusivity of an impact of the rapid progress in education of that time on the modernization of all spheres of public life. The attention of Polish colleagues to the schooling of their eternal neighbors, first of all, Ukrainians is of certain importance as well. An active communication between Polish and Ukrainian scholars and their cooperation in many international research projects (for example, "Krakow-Lviv: books, periodicals, libraries of the $19^{\text {th }}$ and $20^{\text {th }}$ centuries», "Galicia 1772-1918》 and «Lviv: the city - society - culture») make an important prerequisite for finding a consensus on most of the disputable issues.

Key words: Polish historiography, education, schooling, modernization, elementary schools, grammar school, university.

Ref. 31 . 


\title{
Богдан ЯНЫШИН,
}

кандидат исторических наук, старший научный сотрудник отдела истории Украины XIXначала ХХ в. Института истории Украины НАН Украинь

(Киев, Украина), bogdanyanyshyn@gmail.com

\section{ОБРАЗОВАНИЕ В ВОСТОЧНОЙ ГАЛИЧИНЕ АВТОНОМНОГО ПЕРИОДА В ИЗБРАННОЙ ПОЛЬСКОЙ ИСТОРИОГРАФИИ}

\begin{abstract}
Статья посвящена особенностям исследования проблем образования в Восточной Галичине автономного периода в избранной современной польской историографии. Рассмотрены разноплановые работы, посвященные становлению и развитию народного, среднего и высшего образования. Сделан вывод о большой популярности этой проблемы, учитывая сильное модернизаторское влияние образования на все сферы общественной жизни.

Ключевые слова: польская историография, образование, элементарныле иколь, гимназии, университет, модернизация.
\end{abstract}

Лит. 31.

Постановка проблеми. Галичина автономічної доби традиційно $є$ одним із найбільш популярних періодів для польських дослідників минулого. Це й зрозуміло, адже ще в XIX ст. у громадському дискурсі край було марковано як національний П'ємонт, з якого мало розпочатись - i таки розпочалося - відродження польської державності. При цьому особлива увага прикута до освітніх процесів, котрі, завдячуючи самоврядному статусу Галичини, показали найбільшу позитивну динаміку, в порівнянні з іншими сферами тогочасного громадського життя. Саме успіхами шкільництва всіх рівнів польські вчені вповні аргументовано пояснюють скріплення національної свідомості серед широких мас, успішне долання неписемності, виховання чисельної інтелігентської верстви, з представників якої було утворено ефективний державний апарат у перші роки відновленої незалежності.

Аналіз досліджень. 3 огляду на сказане, цілком природною є небуденна зацікавленість польських учених галицьким шкільництвом автономічної доби. Про популярність цієї проблематики промовисто говорить хоча б обсяг укладеної в 1992 р. бібліографії праць, присвячених згаданому питанню [2]. Оскільки польська педагогічна історіографія до 1986 р. вже була предметом спеціального аналізу [5], зосередимося на огляді літератури останнього тридцятиліття. При цьому обмежимо увагу східногалицьким регіоном, де у взаємній конкуренції та взаємовпливах розвивалися освітні системи домінуючих національних громад - українців, поляків і євреїв.

Мета статті - відтворити особливості дослідження проблем східногалицького шкільництва автономічної доби у вибраній сучасній польській історіографії.

Виклад основного матеріалу. Правові аспекти функціонування шкільництва на теренах Галичини доби автономії у спеціальній статті проаналізував Роман Пельчар [13]. Він вказав на провідні тенденції прийнятого в другій половині 1860 - на початку 1870-х рр. освітнього законодавства Австро-Угорської монархії - ліквідацію домінування церкви в цій галузі, навчання національними мовами та надання освітніх прав найширшим суспільним верствам. Підсумком, твердить люблінський дослідник, стало динамічне зростання кількості навчальних закладів всіх рівнів, що дозволило радикально змінити освітній ландшафт краю.

Багатоплановістю охоплюваної проблематики (становлення, поширення, дидактичне забезпечення тощо) характеризуються сучасні дослідження над народним шкільництвом. Його важливість була зумовлена тим, що в Галичині спостерігався найбільший в імперії рівень анальфабетизму - в 1868 р. заледве 34\% дітей відвідувало школу. Однією з найбільш дражливих проблем народної ланки шкільництва польські дослідники слушно називають мову викладання, адже про неї вирішували місцеві органи влади, що нерідко породжувало конфлікти між представниками титульних націй краю. При цьому звертається увага на той факт, що якщо на початку конституційної ери переважали народні школи з українською викладовою мовою, то на схилку Дунайської монархії на перше місце вийшли польські елементарні навчальні заклади [4, 512-513]. Симптоматично, що серед причин такої некорисної для українців динаміки виразно замовчується тен- 
денційна політика здомінованої поляками освітньої влади краю. Водночас слід погодитися зі спостереженням, що поряд із відставанням темпу заснування шкіл відповідно до потреб суспільства, не меншою проблемою було нерозуміння багатьма батьками потреби навчання дітей. Зрештою, робиться вповні аргументований висновок про гідне подиву зростання елементарної освітньої ланки, адже якщо в 1870 р. було 2374 народні школи, то в останній передвоєнний рік їх нараховувалося понад 6000 [6, 32].

Специфіку організації елементарних шкіл у сільській місцевості на підставі мемуарної літератури спробував реконструювати згадуваний вище Р. Пельчар [12]. Дослідник відтворив ставлення селян до елементарної освіти та висвітлив особливості функціонування шкіл у галицькому селі. Автор статті дійшов цікавого висновку, що вплив елементарних шкіл на загальний рівень освіти сільського населення не був надзвичайно великим. Тут більшу роль відігравала особистість учителя, що міг переконати батьків віддати дитину до школи та зацікавити сільську молодь знаннями, а не сам факт існування такого навчального закладу. До подібних висновків у своєму дослідженні дійшов також А. Горбовський [9].

Поряд зі згаданими сюжетами галицького шкільництва, польські дослідники також тривалий час досліджують історію та форми діяльності парафіяльних шкіл, розвиток мережі цих закладів і впливи на них, поряд із римо- та греко-католицькими конфесіями, також державних інституцій і громадськості. Згадаємо тут змістовну монографію Флорентини Жеменюк, у якій всебічно розглянуте уніатське шкільництво та переконливо відтворено його вплив на подолання альфабетизації галицького суспільства [18].

Найбільше уваги польські дослідники присвячують середній ланці шкільництва, насамперед у класичній формі, що можна пояснити її вагомістю у згаданій вище справі виховання численних кадрів національної інтелігенції. І у цьому випадку, як аргументовано показують польські дослідники, Галичина також демонструвала стрімкий кількісний поступ: якщо на початку 60-х рр. XIX ст. існувало лише 19 гімназій, то напередодні війни їх уже було 128 [6, 33]. Під цим оглядом Галичина виразно випереджала інші регіони імперії, якщо взяти до уваги кількість учнів середньої освітньої ланки з розрахунку на 1000 мешканців краю. При цьому, звісно, домінувало польське середнє шкільництво, котрим з особливим завзяттям опікувалися крайові органи влади та численні меценати. Причини ж надто повільного зростання кількості українських гімназій польські дослідники також схильні пояснювати фінансовою незаможністю та певною громадською апатією українців, при цьому зовсім ігноруючи нерідко шовіністичну поставу галицьких урядів, що неодноразово ставала причиною запеклих сеймових баталій та голосних медійних дискусій.

Спеціально проблему утворення та фінансування приватних середніх навчальних закладів у кількох статтях 3’ясувала Марія Стінія [20; 21]. Швидкі темпи в цьому освітньому сегменті краківська дослідниця переконливо пояснила як ліберальним характером імперського законодавства (за яким приватну школу міг заснувати кожен, хто мав на це кошти), так і стрімкою емансипацією галицького суспільства, котре дедалі більше пов'язувало кар'єрний успіх молодого покоління 3 якістю отриманої освіти. Ефектом стало збільшення приватних гімназій протягом автономної доби з 2 до 72! 3 іншого боку, це призвело до певного «перевиробництва» інтелігенції в краю, що навіть стало приводом для галицьких консерваторів обстоювати рацію кількісного зменшення середніх навчальних закладів.

Поряд із класичною середньою освітою, польські дослідники також уважно ставляться до іiі професійної ланки. В сучасних студіях наголошується на вагомості розвитку середньо-спеціальної освіти для прогресу промислового розвитку Галичини та зростанні якості життя тогочасного суспільства $[6,34]$. Поряд із спеціальними студіями, що присвячені, наприклад, медичній [28] та торгівельній [26] освіті, польська наука може похвалитися спеціальною монографією цієї проблеми авторства Єжи Кравчика [11].

У центрі дослідження проблем минулого вищого шкільництва очікувано перебуває найбільш авторитетний навчальний заклад - Львівський університет. Крім вагомості цієї інституції у справі підготовки наукової та адміністративної еліти, увага до головного вишу краю підігрівалася також відзначеним в 2011 р. 350-літнім його ювілеєм, що його польські дослідники рахують від фундаційного акту Яна Казимира. Як відомо, українські історіографи початком Львівського універси- 
тету вважають фундацію Йосифа II від 1784 р. Згаданому ювілеєві було присвячено низку конференцій, серед яких найбільш репрезентативною була краківська. Ефектом конференції стала об’ємна колективна монографія [30], в якій найбільше місця було відведено часу існування університету в добі галицької автономії.

Автори книги послідовно та надзвичайно ретельно розглянули розвиток в університеті всіх наукових галузей, показавши його беззаперечний вплив на поступ польської інтелектуальної культури. При цьому, на жаль, на периферії опинилися українські студії в університеті, про які було згадано лише похапцем, а місцями й тенденційно. Для прикладу наведемо розділ Кшиштофа Стопки, присвячений розвиткові історичних дисциплін у стінах львівської альма-матер. У своєму нарисі краківський дослідник, зупиняючись на проблемі утворення до початку Першої світової війни історичних шкіл в університеті, згадав лише схоларні практики польських професорів [23, 229]. Вказавши, що з наукового семінару М. Грушевського «виводиться ціла генерація українсько-галицьких істориків», різнобічну діяльність самого вченого К. Стопка схарактеризував вкрай тенденційно - цілковито у войовничому дусі польської публіцистики початку ХХ ст. [23, 245-246].

Значно об'єктивніші оцінки містяться в іншій колективній монографії, присвяченій історії та історикам Львівського університету, що стала результатом співпраці жешувських та львівських науковців [8]. І в цій праці, що охопила минуле інституції до початку Другої світової війни, періоду його розвитку в автономічну добу було присвячено найбільше місця. У книзі з подиву гідною ретельністю реконструйовано становлення в стінах університету багатьох галузей історичного знання, вказано на вагомість творчого та дидактичного доробку львівських професорів і доцентів.

Доволі багато сьогодні у польських опрацюваннях йдеться про наростання польсько-українського конфлікту в стінах університету. Слушно вказуючи на пов'язаність цього явища із загальною суспільно-політичною ситуацією в краї, польські колеги все-таки схильні вбачати в українцях нерідко єдиних ініціаторів заворушень у столичному виші. Для прикладу наведемо присвячену М. Грушевському монографію Лукаша Адамського. Некритично послуговуючись польською галицькою публіцистикою кінця XIX - початку XX ст., варшавський дослідник багатократно характеризує львівського професора «упертим у радикалізмі» громадським діячем і відзначає його винятково деструктивний вплив на молодь [1]. Про тенденційність автора говорить, приміром, і той факт, що попри значну українську історіографію проблеми національного протистояння в університеті, винуватцями вбивства Адама Коцка безапеляційно названо самих же українських студентів!

Спробу збірного портрету вищих галицьких навчальних закладів запропонувала Малгожата Весоловська [31]. Вона змалювала кількісну динаміку доцентсько-професорської корпорації, студентського складу та навчальних предметів, а також розглянула специфіку фінансування вищої освіти. У підсумку краківська дослідниця вказала на видатну роль вищого шкільництва як у справі модернізації галицького суспільства, так і швидкого поступу самого наукового знання.

Поряд зі зрозумілою підвищеною увагою до польського шкільництва в Східній Галичині, наші західні колеги звертають також увагу на специфіку освітніх процесів у середовищах інших національних громад краю, насамперед, євреїв та українців. Так, питанням становлення та розвитку освіти євреїв присвячено змістовні студії Юзефа Швєбоди [24] та Казімєжа Редзінського [16]. Вповні виправдано зростання зацікавлення громадянською освітою в консервативному єврейському середовищі пояснюється динамічною емансипацією галицької громади, що зачепила всіх без винятку акторів тогочасної політичної сцени.

Немало польські дослідники пишуть і про тогочасне українське шкільництво [27]. При цьому, поряд із коректністю наведеного статичного та фактологічного матеріалу, можемо спостерігати тенденційність у висвітленні проблем поступу освіти українців краю. Для прикладу згадаємо цікаву спробу Юзефа Швєбоди цілісно представити галицьке шкільництво під кутом зору його національних особливостей [25]. Сумлінно узагальнивши та представивши в численних таблицях статистичний матеріал, польський дослідник водночас не зміг відмовитися від сформованих протягом першої третини XX ст. стереотипів при інтерпретації тих чи тих тенденцій «русинського» шкільництва в краї. Так $\epsilon$, наприклад, у випадку пояснення причин наростання польсько-україн- 
ського протистояння, що значною мірою загострювалося через відверте нехтування польською адміністрацією краю природних, врешті, закріплених законом, освітніх потреб і вимог українців. Як і польські публіцисти кінця XIX - початку XX ст., він однозначно змальовує українську інтелігенцію «шовіністами», порушниками нібито віковічної польсько-української «гармонії» $[25,117-118]$. Іншим прикладом авторської тенденційності є спроба пояснити значно стрімкіше зростання кількості польських навчальних закладів «вищим розвитком [польської] культури та розумінням значення навчання в житті суспільства», аніж це було серед українців $[25,120]$. При цьому зовсім не беруться до уваги загальнознані багаторічні намагання українських політиків збільшити коштом державного бюджету кількість народних шкіл і гімназій, що всіляко гальмувалося польською більшістю Галицького сейму. Не витримує критики також теза про те, що кількість народних українських шкіл була надмірною, що «не відповідало потребам» корінного населення Східної Галичини [25, 130].

Порівняно небагато праць протягом досліджуваного періоду було присвячено організації та діяльності галицьких освітніх інституцій, насамперед Крайової шкільної ради та підлеглих їй адміністративних структур - окружних та місцевих рад. Кілька документів з фонду Польського педагогічного товариства у Львові (два протоколи засідань Президії та протокол Х Загального з'їзду делегатів товариства), що сформований у ЦДІАУЛ, опублікувала Малгожата Пшеньосло [14]. У передмові до видання цих матеріалів дослідниця коротко змалювала історію ПТП. Натомість, здебільшого про польські освітні товариства згадується у загальних нарисах галицького шкільництва [4, 513].

Проблему фінансування освітньої галузі надалі досліджує знаний краківський учений Юліан Дибєц. Його фактографічно насичені праці, присвячені проблемі «цивілізаційних інвестицій», переконливо показують жертовність польської громади на освітні та наукові справи. Це дозволило, поряд із розгалуженою мережею державних навчальних закладів, закладати й утримувати численні школи різних типів і ступенів [7].

Доволі багато в сучасних польських студіях йдеться про освіту для дівчат, поява якої пояснюється одним із проявів суспільної емансипації. Про важливість цього питання, твердять дослідники, свідчить той факт, що в добі автономії діяло 78 таких шкіл елементарного рівня, 6 учительських семінарій, 5 ліцеїв та 7 реальних гімназій [3]. При цьому особливо вагомий вплив на освіту дівчат, як свідчать численні праці польських дослідників, мала церква [17]. Згадані школи, твердять дослідники, мали неабиякий цивілізаційний вплив на галицьку громаду. Суспільна емансипація була також причиною появи шкіл для дорослих, котрі вперше виникають саме в добу галицької автономії. Цю важливу проблему в спеціальних розвідках всебічно дослідили Р. Терлецький [29] та А. Стопінська-Пайонк [22].

Практично відсутні на сьогодні дослідження над важливою проблемою прописування освітнього сегменту в просторі тогочасних галицьких містах. Увага польських дослідників цілком очікувано сфокусована на містах західної частини краю. Зі східногалицьких міст маємо на сьогодні фактично єдину спробу Лукаша Сроки реконструювати освітянську політику урядників Львова та показати місце освіти й освітян у житті столиці провінції [19, 153-159].

Важливою стороною освітнього процесу є особа вчителя. Педагогічне середовище автономної Галичини також тривалий час перебуває у полі зору польських дослідників. Поряд зі значною кількістю досліджень статейного формату, маємо на сьогодні й кілька змістовних монографічних опрацювань. Так, Генрика Крамаж зробила вдалу спробу змалювання історично-соціологічного портрету гімназійних учителів [10]. А іiі люблінська колега Аліція Пушка зосередилася на проблемах професійного вишколу, дидактичної праці, наукової та громадської активності вчителів історії та географії [15]. Що важливо, обидві згадані дослідниці аналізують також і український сегмент галицької педагогічної корпорації.

Висновки. Проведений аналіз дає підставу констатувати значну зацікавленість польських учених різноманітними проблемами та всіма формами східногалицького шкільництва автономічної доби. Дослідники одностайні у своїх висновках щодо винятковості впливу стрімкого освітнього поступу того часу на модернізацію усіх сфер суспільного життя. Важливою для нас $є$ також увага польських колег до шкільництва їхніх одвічних сусідів, насамперед українців. При цьому вка- 
жемо на побутування у деяких вищезгаданих працях стереотипів при осмисленні українського шкільництва краю, котрі перейшли нам у спадок від доби гострого міжнаціонального протистояння. Втім, активна комунікація польських та українських науковців, їхня співпраця в багатьох міжнаціональних дослідницьких проектах (наприклад, «Краків-Львів: книги, часописи, бібліотеки XIX та XX ст.», «Галичина 1772 - 1918» та «Львів: місто - суспільство - культура»), є важливою передумовою віднаходження консенсусу з більшості дискусійних проблем.

\section{СПИСОК ВИКОРИСТАНИХ ДЖЕРЕЛ І ЛІТЕРАТУРИ}

1. Adamski Ł. Nacjonalista postępowy. Mychajło Hruszewski i jego poglądy na Polskę i Polaków / Łukasz Adamski. - Warszawa: Wydawnictwo Naukowe PWN, 2011. - 369 s.

2. Bibliografia dziejów oświaty i wychowania w Galicji 1772 - 1918. Pod. red.A. Meissnera i St. Mońżdżenia. - Rzeszów, 1992. - $250 \mathrm{~s}$.

3. Bilewicz A. Prywatne ogólnokształcące szkolnictwo żeńskie w Galicji w latach 1867 - 1914 / A. Bilewicz // Acta Universitatis Wratislaviensis No 1897. Prace Pedagogiczne CXVI. - 1997. - S. 115-119.

4. Chwalba A. Historia Polski 1795 - 1918 / Andrzej Chwalba. - Warszawa: Wydawnictwo Literackie, 2001. $-671 \mathrm{~s}$.

5. Dutkowa R. Oświata i wychowanie w Galicji w polskiej historiografii ostatniego czterdziestolecia / Renata Dutkowa // Przegląd Historyczno-Oświatowy. - 1986. - № 4. - S. 395-429.

6. Dybiec J. Galicja na drodze do wielkiej przemiany / Julan Dybiec // Kraków i Galicja wobec przemian cywilizacyjnych (1866 - 1914). Studia i szkice, red. Krzysztof Fiołek, Marian Stala. - Kraków, 2011. - S. 31-42.

7. Dybiec J. Życie naukowe w Galicji doby autonomicznej // Galicja i jej dziedzictwo. Tom 3. Nauka i Oświata. - Rzeszów: Wydawnictwo Wyższej Szkoły Pedagogicznej, 1995. - S. 7-18.

8. Historia w Uniwersytecie Lwowskim. Badania i nauczanie do 1939 roku. Red.: Jerzy Maternicki, Joanna Pisulińska, Leonid Zaszkilniak. - Rzeszów: Wydawnictwo Uniwersytetu Rzeszowskiego, 2016. - 662 s.

9. Horbowski A. Drogi edukacyjne dziecka wsi galicyjskiej / A. Horbowski // Historia wychowania. Misja i edukacja, red. K. Szmyd, J. Dybiec. - Rzeszów, 2008. - S. 5-19.

10. Kramarz H. Nauczyciele gimnazjalni Galicji 1867 - 1914 / Henryka Kramarz. Studium historycznosocjologiczne. - Kraków, 1987. - 322 s.

11. Krawczyk J. Galicyjskie szkolnictwo zawodowe w latach 1860 - 1918 / Jerzy Krawczyk. - Kraków: Universitas, 1995. $-295 \mathrm{~s}$.

12. Pelczar R. Miejsce wiejskich szkół elementarnych i ich nauczycieli w życiu społeczności chłopskich w Galicji / Roman Pelczar // Galicja. Studia i materiały. Czasopismo Instytutu Historii Uniwersytetu Rzeszoskiego. Rzeszów, 2015. - 1. - S. 114-133.

13. Pelczar R. Uwarunkowania rozwoju szkolnictwa w Galicji w okresie lat 1772 - 1918 / Roman Pelczar // Karpacki Przegląd Naukowy. - 2013. - Nr. 4 (8). - S. 13-30.

14. Przeniosło M. Polskie Towarzystwo Pedagogiczne we Lwowie (materiały z lwowskiego Archiwum Historycznego) / Małgorzata Przeniosło // Galicja. Studia i materiały. Czasopismo Instytutu Historii Uniwersytetu Rzeszoskiego. - Rzeszów, 2015. - 1. - S. 378-396.

15. Puszka A. Nauczyciele historii i geografii państwowych szkół średnich w Galicji w okresie autonomii (1868 - 1914) / Alicja Puszka. - Lublin: TNKUL, 1999. - 372 s.

16. Rędziński K. Żydowskie szkolnictwo świeckie w Galicji w latach 1813 - 1918 / Kazimierz Rędziński. Częstochowa, 2000. - 283 s.

17. Rogozińska A. Szkóły Sióstr Urszulańek w Tarnowie, Kołomyi, Stanisławowie i we Lwowie / A. Rogozińska // Religie, edukacja, kultura. Księga pamiątkowa dedukowana profesorowi Stanisławowi Litakowi. - Lublin, 2002. - S. 451-457.

18. Rzemieniuk F. Unickie szkoły początkowe w Królewstwie Polskim i w Galicji 1772 - 1914 / Florentyna Rzemieniuk. - Lublin: Tow. Nauk. Katolickiego Uniwersytetu Lubelskiego, 1991. - 348 s.

19. Sroka Ł. T. Rada Miejska we Lwowie w okresie autonomii galicyjskiej 1870 - 1914. Studium o elicie władzy / Łukasz Tomasz Sroka. - Kraków: Wydawnictwo Naukowe Uniwersytetu Pedagogicznego, 2012. - 560 s.

20. Stinia M. Rola społeczeństwa galicyjskiego jako organizatora średniego szkolnictwa prywatneo w okresia autonomii / Maria Stinia // Z dziejów polskiej kultury i oświaty od średniowiecza do początków XX wieku, red. Krzysztof Jakubiak, Tomasz Maliszewski. - Kraków: Impuls, 2010. - S. 133-144.

21. Stinia M. Szkolnictwo prywatne autonomicznej Galicji: nie tylko c.k. / Maria Stinia // Wiadomości Historyczne. - 2010. - R. 53. - № 2. - S. 13-17.

22. Stopińska-Pająk A. Polska oświata dorosłych w Galicji na przełomie XIX i XX wieku/A. Stopińska-Pająk // Galicja i jej dziedzictwo. - Tom 3. Nauka i oświata. - Rzeszów: Wydawnictwo Wyższej Szkoły Pedagogicznej, 1995. - S. 23-34. 
23. Stopka Krz. Nauki historyczne na Uniwersytecie Lwowskim / Krzysztof Stopka // Uniwersytetowi Lwowskiemu dla upamiętnienia trzysta pięćdziesiątej rocznicy jego fundacji. Materiały sesji zorganizowanej w dniach 14-15 stycznia 2011 w Krakowie. - Kraków: Polska Akademia Umiejętności, 2011. - S. $225-266$.

24. Świeboda J. Edukacja Żydów w Galicji 1772 - 1918 / Józef Świeboda // Prace Historyczno-Archiwalne. - 1994. - T. II. - S. 85-131.

25. Świeboda J. Problemy narodowościowe w szkolnictwie galicyjskim (1772 - 1918) / Józef Świeboda // Analecta: studia i materiały z dziejów nauki. - 1995. - Tom 4. Numer 2 (8). - S. 97-144.

26. Świeboda J. Szkolnictwo handlowe w Galicji / Józef Świeboda // Analecta: studia i materiały z dziejów nauki. - 2010. - Tom 19. - Numer 1-2 (36-37). - S. 203-272.

27. Świeboda J. Szkolnictwo ukraińskie w Galicji (1772 - 1918), Stan badań i potrzeby / J. Świeboda // Galicja i jej dzidzictwo. - T. 8: Myśl edukacyjna w Galicji 1772 - 1918: Ciągłość i zmiana. - Rzeszów: Wyd-wo WSP, 1996. - S. 271-291.

28. Świeboda J. Średnie szkolnictwo medyczne w Galicji / Józef Świeboda // Archiwum Historii i Filozofi Medycyny. - 1995. - Z. 4. - S. 397-414.

29. Terlecki R. Oświata dorosłych i popularyzacja nauki w Galicji w okresie autonomii / R. Terlecki. Wrocław: Zakład Narodowy im. Ossolińskich, 1990. - 262 s.

30. Uniwersytetowi Lwowskiemu dla upamiętnienia trzysta pięćdziesiątej rocznicy jego fundacji. Materiały sesji zorganizowanej w dniach 14-15 stycznia 2011 w Krakowie. - Kraków: Polska Akademia Umiejętności, 2011. $-531 \mathrm{~s}$.

31. Wesołowska M. Uczelnie galicyjskie doby autonomii / Małgorzata Wesołowska // Zeszyty Naukowe Uniwersytet Ekonomiczny w Krakowie. - № 12(960). - S. 107-124.

Стаття надійила до редакияї 21.10.2017 p. 